at the Park Prewett Hospital in Basingstoke, where we were assigned a block of wards with 300 beds. We developed our own operating room in a bath-house and proceeded to bring over additional doctors, nurses and personnel and developed our facilities to a satisfactory level and were able to receive and treat patients. In January 1942 our much expanded unit moved to Oxford to take over the operation of the new Churchill Hospital which had just been constructed by the Emergency Medical Service. Our hospital unit was, however, now to become a dwindling operation as the United States had entered the war; it was purely a matter of holding on in Oxford until we could be relieved by a regular medical unit of the army, and this was done on July 1, 1942.

It was after the war that " H. P." assumed the proportions of a great international figure. He had been knighted in 1948, and from 1954 to 1957 he served as President of the Royal College of Surgeons of England. He received honorary degrees from the Universities of Berne, Manchester, Liverpool, Belfast and Leeds, and in 1958 was made a baronet. He has aged well, like good wine, and still keeps interested in working in all good causes. As my oldest friend in the orthopaedic speciality I salute him on his eightieth birthday, and as one octogenarian to another I wish him many more.

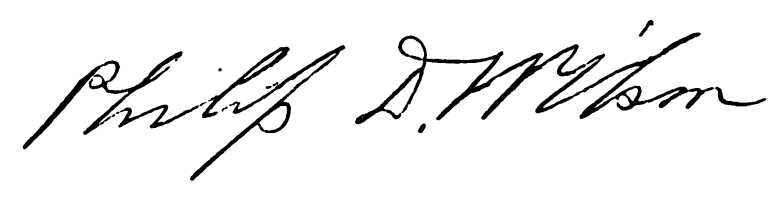

\title{
ASSOCIATIONS WITH THE ROYAL COLLEGE OF SURGEONS OF ENGLAND
}

\author{
Sir James Paterson Ross, London, England
}

Past-president, Royal College of Surgeons of England

In recounting the associations of Harry Platt with the Royal College of Surgeons one might naturally start with his election to the Council in 1940, but that would omit a significant incident that occurred twenty years earlier. John Morley tells how after the first meeting of the Association of Surgeons at the College he, with Harry Platt and Geoffrey Jefferson, all recently appointed consultants and taking legitimate pride in their fellowship of the new Association, went to have tea in the Lyons shop at the corner of Lincoln's Inn Fields. They were joined at the table by Sir Rickman Godlee who, overhearing their conversation and wishing to be sociable, enquired if they were in for the conjoint examination which was on at the time. How was he to know that he was addressing three future leaders of the profession, one of whom would be president of the College at a critical period in its history?

Gordon-Taylor and Webb-Johnson were re-elected, and Harry Platt and Zachary Cope were elected to the Council on July 4, 1940, only a few months before the College was grievously damaged by bombing. For Sir Harry himself the horror and dismay of the disaster might have been mitigated had he realised then that he would be destined to play so prominent a part in the restoration and extension of the buildings, of which a great section, including the Edward Lumley Hall with the enlarged departments of Pathology and Anatomy above it, and also the Nuffield College, came fully into use during his presidency.

VOL. 48 B, NO. 4, NOVEMBER 1966 
By virtue of his special knowledge of the provision made for orthopaedic patients by the Ministry of Health and the Ministry of Labour Harry Platt was able to represent the interests of the College in matters relating to the rehabilitation, training and employment of disabled persons, and in 1944 when the Council decided to formulate its own opinion on these matters he was chosen to serve on the Committee appointed to undertake the task. Indeed his understanding of the organisation and administration of the National Health Service has been of the greatest value to the Ministry as a Consultant Adviser, and to the College in helping to harmonise the staffing requirements of the Service with the training of surgeons. It would be utterly wrong, however, to regard him as a medical politician promoting the interest of any professional group; his rôle has ever been that of the political philosopher, making a wide survey of a problem and seeking the solution which offered the greatest advantage to the majority of those concerned.

His interest in education as distinct from training dated at least from his early days in Boston, when he was able to appreciate at first hand the advantage to a clinical professor of " having the key of the door," and thus being able to select for admission the patients whose maladies were of particular importance to the work of the clinic. Seeing the need for a forum for the discussion of the problems of clinical education he persuaded John Ryle, Geoffrey Jefferson and Hugh Cairns and then seven other clinical professors to meet and talk the matter over, which they did in Oxford on January 4, 1942. Such was the origin of the 1942 Club which still flourishes, on a greatly enlarged scale, and can fairly claim to be continuing to fulfil the objective which its founder had in mind. It was natural, therefore, for Sir Harry to give his active support to the plans for establishing in the Royal College of Surgeons the Institute of Basic Medical Sciences, which became an Associated Institute of the British Postgraduate Medical Federation in 1954, with Sir Reginald Watson-Jones as Chairman of the Committee of Management and Professor Geoffrey Hadfield as Dean. Thus an organic link was forged between the College and the University of London.

Sir Harry was President of the College from 1954 till 1957, three eventful and satisfying years which witnessed several important innovations in the life of the College, and included the admission of Sir Winston Churchill to the Honorary Fellowship. During this period the Court of Patrons was instituted; the annual meeting of Fellows and Members took place for the first time in a provincial centre, most appropriately in Manchester; a joint meeting with the Academie de Chirurgie de Paris was held at the College; and, in collaboration with our sister college in the United States, the foundations were laid of the International Federation of Surgical Colleges, of which Sir Harry later became the first president. The value to the College of his familiarity with various British statutory bodies and voluntary organisations concerned with matters surgical has already been mentioned; of equal importance has been his acquaintance with surgical colleagues in foreign countries, their practice, their clinics and their training, which, combined with his friendly and understanding approach, has made it easy for the College to establish cordial relations with many academic institutes overseas.

British surgery indeed owes much to Harry Platt's wise leadership at a time when the Royal College of Surgeons of England was assuming its proper rôle in education and international affairs, and it is comforting that his good counsel is still available to those responsible for dealing with the problems of today.

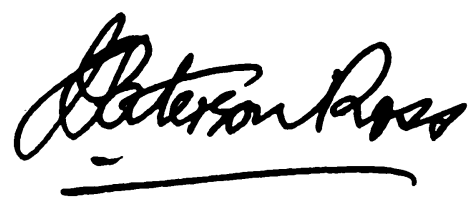

